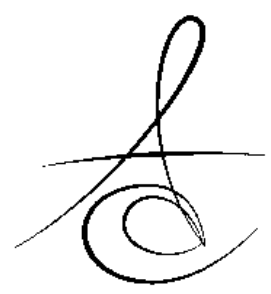

\section{EVALUATION OF RADIOPAQUE LESIONS OF THE JAW BONES ON DIGITAL PANORAMIC RADIOGRAPHY IN A TURKISH SUBPOPULATION: A RETROSPECTIVE STUDY}

\section{BİR TÜRK SUBPOPÜLASYONUNDA DİJİTAL PANORAMİK RADYOGRAFİDE ÇENE KEMİKLERİNDE GÖRÜLEN RADYOOPAK LEZYONLARIN DEĞERLENDİRİLMESİ: BİR RETROSPEKTİF ÇALIŞMA}

Arş. Gör. Büşra ARIKAN *

\author{
Makale Kodu/Article code: 4520 \\ Makale Gönderilme tarihi; 21.07 .2020 \\ Kabul Tarihi; 08.02.2020 \\ DOI : $10.17567 /$ ataunidfd.837436
}

Numan Dedeoğlu: ORCID ID: 0000-0003-0892-3654

Büşra Arıkan: ORCID ID: 0000-0002-6315-3827

\title{
ABSTRACT
}

Aim: Panoramic radiography is one of the most basic diagnostic tools in today's dentistry in addition to being the initial examination radiography. The aim of this study is to evaluate radiopaque lesions of the jaw bones by using digital panoramic radiography images in a Turkish subpopulation.

Materials and Methods: This study was conducted by evaluating digital panoramic radiography images of 1011 patients. In this study, the incidence of radiopaque lesions of idiopathic osteosclerosis, condensing osteitis, odontoma, cementoblastoma, cemento-osseous dysplasia and fibrous dysplasia were evaluated in addition to gender and localization. Descriptive statistics, chi-square and fisher exact tests were used in the evaluation of the data.

Results: In this study, 1011 digital panoramic radiographs were evaluated, 549 (54.3\%) of these belonged to female patients and 462 (45.7\%) belonged to male patients. Radiopaque lesions were determined on 76 (7.5\%) panoramic radiography. While idiopathic osteosclerosis was found in $42(4.15 \%)$, condensing osteitis was found in 23 (2.27\%), odontoma was found in 2 $(0.19 \%)$, cementoblastoma was found in $1(0.09 \%)$, cemento-osseous dysplasia was found in $7(0.69 \%)$ and fibrous dysplasia was found in $1(0.09 \%)$. No statistically significant difference was found between genders in any of the lesions ( $p>0,05)$.

Conclusion: Radiopaque lesions of the jaws can be evaluated with digital panoramic radiography, which is widely used today. The most common radiopaque lesion in this study was idiopathic osteosclerosis, while the least common was sementoblastoma and fibrosis dysplasia.

Key words: panoramic radiography, condensing osteitis, odontoma, fibrous dysplasia

Öz

Amaç: Panoramik radyografi günümüz diş hekimliğinde başlangıç tetkik radyografi olmasıyla beraber en temel diagnostik araçlardan biridir. Bu çalışmanın amacı bir Türk subpopulasyonunda dijital panoramik radyografi görüntüleri kullanarak çene kemiklerinde görülen radyoopak lezyonların değerlendirilmesidir.

Gereç ve Yöntemler : Bu çalışma 1011 hastaya ait dijital panoramik radyografi görüntüleri değerlendirilerek gerçekleştirildi. Bu çalışmada radyoopak lezyonlardan idiopatik osteosklerozis, kondensing osteitis, odontoma, sementoblastoma, sementoosseoz displazi ve fibröz displazinin görülme sıklığıyla beraber, cinsiyet ve lokalizasyon değerlendirilmeleri yapıldı. Verilerin değerlendirmede tanımlayıc istatistikler, ki kare ve fisher exact testleri kullanıldı.

Bulgular : Bu çalışmada 549 (\%54.3)' u kadın, 462(\%45.7)'si erkek hastaya ait olmak üzere 1011 dijital panoramik radyografi değerlendirildi. Radyoopak lezyon 76 (\%7.5) panoramik radyografide belirlendi. 42 (\%4.15) idiopatik osteosklerozis, 23 (\%2.27) kondensing osteitis, $2(\% 0.19)$ odontoma, $1(\% 0.09)$ sementoblastoma, $7(\% 0.69)$ sementoosseoz displazi ve $1(\% 0.09)$ fibroz displazi bulundu. Lezyonların hiçbirinde cinsiyetler arasında istatistiksel olarak anlamlı bir fark bulunmadı $(p>0,05)$. Sonuç: Günümüzde yaygın olarak kullanılan dijital panoramik radyografi ile çenelerin radyoopak lezyonları değerlendirilebilmektedir. Bu çalışmada görülme sıklı̆ı en fazla bulunan radyoopak lezyon idiopatik osteosklerozis iken en az bulunan ise sementoblastoma ve fibroz displazidir.

Anahtar kelimeler : panoramik radyografi,kondensing osteitis, odontoma, fibröz displazi

* Inonu University, Faculty of Dentistry Department of Oral and Maxillofacial Radiology, Malatya

Kaynakça Bilgisi: Dedeoğlu N, Arıkan B. Bir türk subpopülasyonunda dijital panoramik radyografide çene kemiklerinde görülen radyoopak lezyonların değerlendirilmesi: bir retrospektif çalışma. Atatürk Üniv Diş Hek Fak Derg 2021; 31: 154-9.

Citation Information: Dedeoglu N, Arikan B. Evaluation of radıopaque lesıons of the jaw bones on digital panoramı radıography in a turkısh subpopulatıon: a retrospective study. J Dent Fac Atatürk Uni 2021; 31: 154-9. 


\section{INTRODUCTION}

Studies on lesions of jaw bones are important for clinicians' diagnosis and treatment planning. A great majority of these lesions are seen on routine radiography, while some of them are noticed as a result of swelling or pain and in this case, evaluation is made with panoramic radiography. ${ }^{1}$ Many studies on lesions of the jaw bones are retrospective and histopathological data are generally used in these studies. However, biopsy is not needed in the diagnosis of some lesions (cemento-osseous dysplasia, idiopathic osteosclerosis and others). Therefore, information about these lesions may be incomplete in the literature. ${ }^{2}$

Increased asymptomatic radiopacity of unknown cause in the jaws is known as idiopathic osteosclerosis and is recognized in routine radiological examinations. ${ }^{3,4}$ Radiopaque areas caused by lowgrade inflammation in the apex of the tooth roots are called condensing osteitis. ${ }^{5}$ Odontomas are benign tumors or hamartomas, which are surrounded by radiolucent tape involving all dental tissues. ${ }^{6,7}$ Benign lesions on tooth roots caused by cement or cementlike tissues formed by cementoblasts are known as cementoblastoma. ${ }^{8}$ Fibroosseous lesions describe a group of lesions usually seen in the jaw and facial bones, in which normal bone tissue is replaced with fibrous tissue and varying amounts of bone and cementum. ${ }^{9}$ Fibroosseous lesions are classified as fibrous dysplasia, cemento-osseous dysplasia and ossifying fibroma. ${ }^{10}$

Panoramic radiographs are one of the most common radiodiagnostic tools used in dentistry and are routinely used for the examination of almost all patients. ${ }^{11}$ In recent years, despite the increasing popularity of cone beam computed tomography for panoramic imaging in dentistry, panoramic radiography is still the main diagnostic tool in practice. ${ }^{12}$

The aim of this study is to retrospectively evaluate the radiopaque lesions (idiopathic osteosclerosis, condensing osteitis, odontoma, cementoblastoma, cemento-osseous dysplasia and fibrous dysplasia) in a population in the Southwest region of Eastern Anatolia by using panoramic radiography.

\section{MATERIAL AND METHODS}

This study was conducted by evaluating randomly selected 1011 digital panoramic radiography images of patients who applied to Inonu University
Faculty of Dentistry Department of Oral and Maxillofacial Radiology between 2015-2019. In this study, images obtained by using Planmeca proline XC (2009, 60-80 kVp, 4-12 mA, 18 second exposure time, Helsinki, Finland) panoramic device were used. Ethics committee approval (2019-305) was received from İnönü University Scientific Research and Publication Ethics Committee before the study was conducted. Digital panoramic images were evaluated at different times by a researcher with five years of experience in digital panoramic image evaluation. The presence of radiopaque lesions (idiopathic osteosclerosis, condensing osteitis, odontoma, cementoblastoma, cemento-osseous dysplasia and fibrous dysplasia) were evaluated retrospectively on panoramic radiographs. In addition, the localizations of these radiopaque lesions seen on panoramic radiography were examined and their relationship with age and gender were also determined. Patients with extensive resection of the jaws such as hemimandibulectomy or hemimaxillectomy and if the panoramic radiographs inadequate in terms of diagnostically were not included in the study. The localizations of radiopaque lesions were recorded according to the incisive, canine, premolar and molar regions of the mandible and maxilla for idiopathic osteosclerosis, condensing osteitis, odontoma and cementoblastoma. For fibroosseous lesions, lesions limited to one tooth relative to maxilla and mandible were recorded as incisive, canine, premolar and molar, while lesions wider than one tooth region were recorded as half jaw and those involving the whole jaw were recorded as whole jaw. In the statistical analysis of the data, descriptive statistics, chi-square and fischer exact tests were used with SPSS 21.0 (IBM, Chicago, USA) program to compare groups $(p<0.05)$.

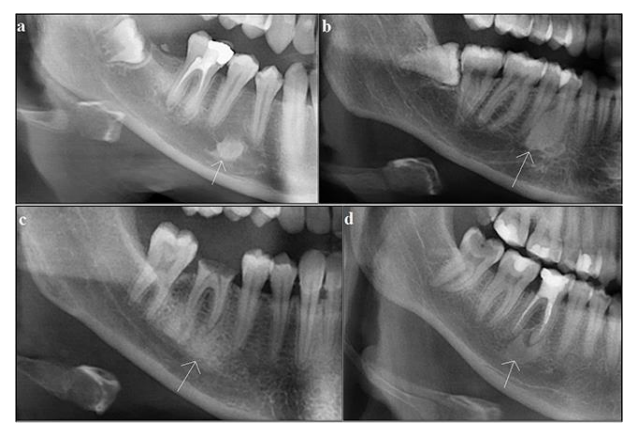

Figure 1. Idiopatic osteosclerosis $(a, b)$ and condensing osteitis $(\mathrm{c}, \mathrm{d})$ with arrow. 


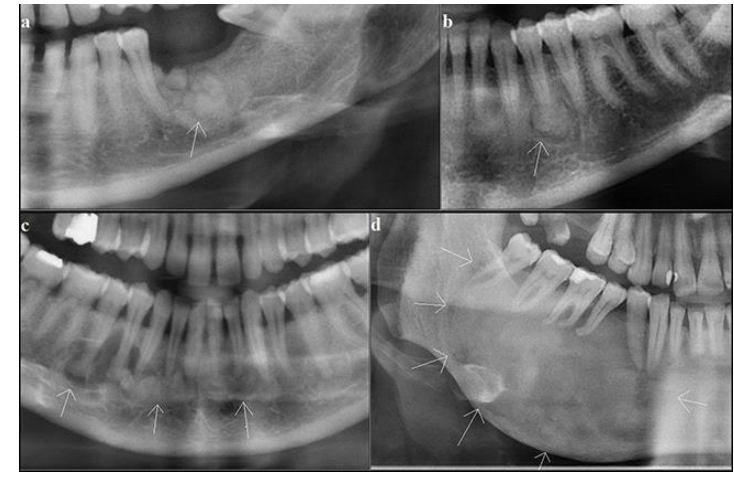

Figure 2. Odontoma (a), cementoblastoma (b), cementoosseos dysplasia (c) and fibrous dysplasia (d) with arrow.

\section{RESULTS}

Of the 1011 patients included in the study, 549 $(54.3 \%)$ were female and $462(45.7 \%)$ were male. The age range of the patients included in the study was 14-90 and their mean age was 35.13 ( \pm 13.83 ). The age range of male patients was between 18-90 and their mean age was 35.05 ( \pm 13.05$)$. The age range of the female patients was between 14-80 and their mean age was 35.23 ( \pm 13.92$)$.

In this study, radiopaque lesions were found in $76(7.5 \%)$ of 1011 patients. $44(8 \%)$ of these lesions were found in women and $32(6.9 \%)$ were found in men. Idiopathic osteosclerosis was seen in a total of $42(4.15 \%)$ patients, $21(3.8 \%)$ female and $21(4.5 \%)$ male. Condensing osteitis was seen in 23 (2.27\%) patients, $15(2.7 \%)$ female and $8(1.7 \%)$ male. Odontoma was found in 2 patients $(0.19 \%)$ and cementoblastoma in 1 patient $(0.09 \%)$, all of the patients with these three lesions were female. Cemento-osseous dysplasia was seen in 7 (0.69\%) patients, $5(0.9 \%)$ female and $2(0.43 \%)$ male. Fibrous dysplasia was seen in $1(0.09 \%)$ male patient (Table 1). No statistically significant difference was found between the genders in the statistical assessment of incidence of radiopaque lesions ( $p=$ 0.513), idiopathic osteosclerosis $(p=0.567)$, condensing osteitis ( $p=0.288)$ and cemento-osseous dysplasia ( $p=0.464$ ) (Table:2).

The distribution of subgroups of radiopaque lesions according to localizations is shown in Table 3 and Table 4.
Table 1. Distribution of radiopaque lesions according to gender

\begin{tabular}{lccr}
\hline & $\begin{array}{c}\text { Female } \\
\mathbf{n ( \% )}\end{array}$ & $\begin{array}{l}\text { Male } \\
\mathbf{n ( \% )}\end{array}$ & \multicolumn{1}{c}{$\begin{array}{l}\text { Total } \\
\mathbf{n ( \% )}\end{array}$} \\
\hline Radiopaque lesions & $44(8)$ & $32(6.9)$ & $76(7.5)$ \\
Idiopatic osteosclerosis & $21(3.8)$ & $21(4.5)$ & $42(4.15)$ \\
Condensing osteitis & $15(2.7)$ & $8(1.7)$ & $23(2.27)$ \\
Odontoma & $2(0.36)$ & - & $2(0.19)$ \\
Cementoblastoma & $1(0.18)$ & - & $1(0.09)$ \\
Cemento-osseous & $5(0.9)$ & $2(0.43)$ & $7(0.69)$ \\
dysplasia & - & & \\
Fibrous dysplasia & - & $1(1.7)$ & $1(0.09)$ \\
\hline
\end{tabular}

Table 2. Statistically comparison of all radiopaque lesions, idiopatic osteosclerosis, condensing osteitis and cementooseous dyplasias between genders.

\begin{tabular}{lccc}
\hline & $\begin{array}{c}\text { Female } \\
\mathbf{n ( \% )}\end{array}$ & $\begin{array}{c}\text { Male } \\
\mathbf{n ( \% )}\end{array}$ & $\mathbf{p}$ \\
\hline Radiopaque lesions & $44(8)$ & $32(6.9)$ & 0.513 \\
Idiopatic osteosclerosis & $21(3.8)$ & $21(4.5)$ & 0.567 \\
Condensing osteitis & $15(2.7)$ & $8(1.7)$ & 0.288 \\
Cemento-osseous dysplasia & $5(0.9)$ & $2(0.43)$ & 0.464 \\
\hline
\end{tabular}

Table 3. Distribution of idiopatic osteosclerosis, condensing osteitis, odontoma and cementoblastoma according to jaws and dental areas.

\begin{tabular}{lrrrrrr}
\hline & Maxilla & Mandibula & [ncisive & Sanine & Premolar & Molar \\
\hline Idiopatic steosclerosis & - & 42 & 1 & 2 & 14 & 24 \\
Condensing osteitis & 4 & 19 & 1 & - & 5 & 17 \\
Odontoma & - & 2 & - & - & - & 2 \\
Cementoblastoma & - & 1 & - & - & 1 & - \\
\hline
\end{tabular}

Table 4. Distribution of fibro osseous lesions according to localizations.

\begin{tabular}{|c|l|c|c|}
\hline fig & $\begin{array}{l}\text { Mandibula } \\
\text { Entire } \\
\text { Hemi }\end{array}$ & $\begin{array}{c}\text { Region of of } \\
\text { maxilla } \\
\text { Incisive canine } \\
\text { premolar molar }\end{array}$ & $\begin{array}{c}\text { Region of of mandibula } \\
\text { Incisive canine premolar } \\
\text { molar }\end{array}$ \\
\hline & & 1 \\
\hline
\end{tabular}

\section{DISCUSSION}

Idiopathic osteosclerosis is a term used for increased dense areas of the bone that are not associated with an inflammatory, neoplastic or systemic disease, and whose cause is unknown. They are usually asymptomatic, they do not cause cortical expansion and they are detected during routine radiological examination. ${ }^{3,43}$ In studies conducted, the incidence of idiopathic osteosclerosis was found between 1.96 and $7.6 \% .{ }^{13-16}$ In our study, the incidence of idiopathic osteosclerosis was found to be $4.15 \%$. Although Miloğlu et $\mathrm{al}^{14}$ and Avramidou et $\mathrm{al}^{13}$

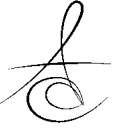


found that the incidence of idiopathic osteosclerosis was higher in women, Williams and Brooks ${ }^{3}$ and Halse and Molven ${ }^{16}$ did not find any differences between the genders in their study. In our study, no statistical difference was found between the genders. In their study, Verzac et $\mathrm{al}^{15}$ and Miloglu et $\mathrm{al}^{14}$ found that idiopathic osteosclerosis was more common in the mandible and molar region. In our study, it was found that all of the idiopathic osteosclrosis were in the mandible and were most commonly seen in the molar region. Treatment and follow-up of idiopathic osteosclerosis lesions detected in adult patients is not necessary. However, since this lesion is developmental, periodic radiographic follow-up of pediatric patients is recommended. 3,17

Condensing osteitis lesions are focal sclerotic lesions that develop at the root end due to lowintensity inflammation in nonvital or inflamed pulp teeth. ${ }^{3,18,44}$ There are many factors in the etiology of condensing osteitis such as deep caries, extensive restorations, inadequate root canal treatments, orthodontic forces, dental eruption and fixed prostheses. 5,19 The incidence of condensing osteitis was found between $0.6-33 \%$ in studies conducted. ${ }^{14,20}$

In our study, the incidence of condensing osteitis was found to be $2.27 \%$. Although Miloğlu et al. ${ }^{14}$ found that the incidence of condensing was higher in women, Williams and Brooks ${ }^{3}$ and Halse and Verzak et $\mathrm{al}^{15}$ did not find any differences between the genders in their study. In our study, no statistical difference was found between the genders. It was found in previous studies that condensing osteitis lesions were more common in the mandible and molar region. ${ }^{14,15}$ In this study, condensing osteitis lesions were more common in the mandible and molar regions. Condensing osteitis lesions disappear after successful endodontic treatment. ${ }^{21}$

Odontomas are known as benign odontogenic tumor involving all dental tissues, but they are also considered to be a hamartoma since they slowly grow and limit their growth after development.6,22,23 Odontomas are classified as complex and compound. ${ }^{6,22-25}$ Once they complete their development, just like a tooth, they will not grow again. ${ }^{26}$ Exact etiology of odontomas is not known. ${ }^{26}$ Odontomas are generally asymptomatic, but they can cause the delay of the eruption of a tooth or tooth retention. ${ }^{6}$ The incidence of odontoma is accepted to be between $0.14-0.8 \% .{ }^{27}$ In our study, the incidence of odontoma was found to be $0.19 \%$. Although the growth of odontomas is limited, they need to be surgically removed because of their potential of bone collapse, problems with permanent tooth eruption and showing cystic change. ${ }^{28}$

Cementoblastoma is a benign neoplasm originating from the accumulation of cement or cement-like tissue on the root surface caused by ectomesence. ${ }^{29,41}$ The prevalence of cementoblastoma in the general population has been reported as $1.79 \% .^{29}$ In our study, the incidence of cementoblastoma was found to be $0.09 \%$. Cementoblastoma occurs in the roots of the mandible premolar or molar teeth and is seen as a wellcircumscribed radiopaque area radiologically surrounded by a radiolucent zone. ${ }^{30}$ A (0.09\%) cementoblastoma found in this study was detected in the premolar tooth root of the mandible. In the presence of cementoblastoma, jawbone expansion, swelling and pain may occur clinically, and if the lesion is completely removed, no recurrence will occur. ${ }^{31}$

Cemento-osseous lesions are lesions of unknown origin, consisting of periodontal ligament and cement or cement-like tissues in the areas of the jaw bones with tooth roots. ${ }^{32}$ They are classified in three groups by WHO. These are focal osseous dysplasia, periapical osseous dysplasia and flouride osseous dysplasia. ${ }^{33}$ Radiological images of these lesions may be radiolucent, mixed and radiopaque depending on the stage they are in. At this stage, the clinician must be careful not to make a misdiagnosis. ${ }^{34,42}$ The incidence of cemento-osseous lesions was found as $0.4 \%$ in a study conducted. In the same study, it was found that these lesions had a higher incidence in women. ${ }^{35}$ In our study, the incidence of cemento-osseous lesion was found as $0.69 \%$. Of the 7 cemento-osseous lesions found in our study, 5 were found in women. Since most of these lesions are self-limited, they require only radiographic follow-up. ${ }^{34}$

Fibrous dysplasias are developmental or probably hamartomatous lesions of unknown origin and they are seen as monostatic at a rate of $80 \% .^{32}$ In the areas where the jawbone is affected, the teeth remain in place, but sometimes displacement can be seen. Tooth root resorption is rare. ${ }^{36,37}$ Fibrous dysplasias appear radiolucent in the early period, while they appear radiopaque and typically as ground glass in the later period. ${ }^{32}$ In fibrous dysplasias which continue with the surrounding bone, the margins of 
the lesion are not clear and they expand. ${ }^{38,39}$ In a histopathological study, the incidence of fibrous dysplasia was found to be $1.87 \% .{ }^{40}$ In our study, the incidence of fibrous dysplasia was found as $0.09 \%$. The management of fibrous dysplasia is conservative. Lesions not causing deformity can be followed. Partial resections can be performed for lesions involving large and multiple bones and deformities. ${ }^{9}$

\section{CONCLUSIONS}

As a conclusion, in this study performed with panoramic radiography, the incidence of radiopaque lesions in the Southwestern part of the population in Eastern Anatolia region in Turkey were found to be, while the lesion with the highest incidence was osteosclerosis, the lesions with the lowest incidence were cementoblastoma and fibrosis dysplasia .

\section{Acknowledgements}

The authors declare that there were no other contributors involved in this work.

Conflicts of interest statement

Numan Dedeoğlu, and Büşra Arıkan declare that they have no conflict of interest.

\section{REFERENCES}

1. Neyaz Z, Gadodia A, Gamanagatti S, Mukhopadhyay S. Radiographical approach to jaw lesions. Singapore Med J 2008;49:165-76.

2. Araujo JP, Lemos CA, Miniello TG, Alves FA. The relevance of clinical and radiographic features of jaw lesions: A prospective study. Braz Oral Res 2016; 30:96.

3. Williams TP, Brooks SL. A longitudinal study of idiopathic osteosclerosis and condensing osteitis. Dentomaxillofac Radiol 1998; 27: 275-8.

4. Gamba TO, Maciel NAP, Rados PV, da Silveira HLD, Arús NA, Flores IL. The imaging role for diagnosis of idiopathic osteosclerosis: a retrospective approach based on records of 33,550 cases. Clin Oral Investig 2021;1-11.

5. Altun O, Dedeoğlu N, Umar E, Yolcu Ü, Acar AH. Condensing osteitis lesions in Eastern Anatolian Turkish population. Oral Surg Oral Med Oral Radiol 2014;2:17-20.

6. An SY, An C, Choi K. Odontoma: a retrospective study of 73cases. Imaging Sci Dent 2012;42:7781.
7. Levi F, Ardila C. Association between odontoma size, age and gender: Multivariate analysis of retrospective data. J Clin Exp Dent 2019;11:701-6.

8. Kramer JR, Pindborg JJ, and Shear M. Histological typing of odontogenic tumours, jaw cysts, and allied lesions. Inter Histological Classific Tumours 1992.

9. Secgin CK, Günhan O, Gulsahı A. Benign fibroosseöz lezyonlar. Acta Odontol Turc 2016; 33: 95-101.

10.Barnes L, Eveson JW, Reichart P, Sidransky D, editors. WHO classification of tumours. Pathology and genetics of head and neck tumours. Lyon: IARC Press; 2005.

11. Farman AG. Panoramic radiology: Role in ADA/FDA use guidelines. In: Farman AG (ed). Panoramic radiology: Seminars on maxillofacial imaging and interpretation. Heidelberg: Springer 2007;33-40.

12. AAPD. Guideline on prescribing dental radiographs for infants, children, adolescents, and persons with special health care needs. Pediatr Dent 2016;38: 355-7.

13. Avramidou FM, Markou E, Lambrianidis T. Crosssectional study of the radiographic appearance of radiopaque lesions of the jawbones in a sample of Greek dental patients. Oral Surg Oral Med Oral Pathol Oral Radiol Endod 2008;106:38-43.

14. Miloglu O, Yalcin E, Buyukkurt MC, Acemoglu H. The frequency and characteristics of idiopathic osteosclerosis and condensing osteitis lesions in a Turkish patient population. Med Oral Patol Oral Cir Bucal 2009;14:640-5.

15. Verzak Ž, Ćelap B, Modrić VE, Sorić P, Karlović Z. The prevalence of idiopathic osteosclerosis and condensing osteitis in Zagreb population. Acta Clin Croat 2012;51:573-7.

16. Halse A, Molven O. Idiopathic osteosclerosis of the jaws followed through a period of $20-27$ years. Int Endod J 2002;35:747-51.

17. Kaplan I, Nicolaou Z, Hatuel D, Calderon S. Solitary central osteoma of the jaws: a diagnostic dilemma. Oral Surg Oral Med Oral Pathol Oral Radiol Endod 2008;106:22-9.

18.MacDonald-Jankowski DS. Idiopathic osteosclerosis in the jaws of Britons and of the Hong Kong Chinese: radiology and systematic review. Dentomaxillofac Radiol 1999;28:357-63.

19.Ledesma-Montes C, Jımenez-Farfan MD, Hernandez-Guerrero JC. Maxillomandibular giant osteosclerotic lesions. J Appl Oral Sci 2018;26. 
20. Ardakani FE, Azam AR. Radiological findings in panoramic radiographs of Iranian edentulous patients. Oral Radiol 2007;23:1-5.

21. Morse DR, Esposito JV, Yesilsoy C. Recall radiopaque response determined from radiographic examination of 211 consecutive cases with initial periapical pathosis. Quintessence Int 1985; 16: 419-28.

22. Owens BM, Schuman NJ, Mincer HH, Turner JE, Oliver FM. Dental odontomas: a retrospective study of 104 cases. J Clin Pediatr Dent 1997; 21: 261-4.

23. Tomizawa $M$, Otsuka $Y$, Noda T. Clinical observations of odontomas in Japanese children: 39 cases including one recurrent case. Int J Paediatr Dent 2005; 15: 37-43.

24. Bordini J Jr, Contar CM, Sarot JR, Fernandes A, Machado MA. Multiple compound odontomas in the jaw: case report and analysis of the literature. J Oral Maxillofac Surg 2008; 66 : 2617-20.

25. Kodali RM, Venkat Suresh B, Ramanjaneya Raju P, Vora SK. An unusual complex odontoma. J Maxillofac Oral Surg 2010; 9:314-7.

26. Baldawa RS, Khante KC, Kalburge JV, Kasat VO. Orthodontic management of an impacted maxillary incisor due to odontoma. Contemp Clin Dent 2011; 2:37-40.

27. Açıkgöz A, Çelenk P, Kayıpmaz S. Odontomaların görülme sıklığı (radyografik çalışma). Ondokuz Mayıs Üniv Diş Hek Fak Derg 1999; 1.

28. Hidalgo-Sanchez O, Leco-Berrocal MI, Martı'nezGonz_alez JM. Metaanalysis of the epidemiology and clinical manifestations of odontomas. Med Oral Patol Oral Cir Bucal 2008;13:730-4.

29 Nuvvula S, Manepalli S, Mohapatra A, Mallineni SK. Cementoblastoma relating to right mandibular second primary molar. Case Rep Dent 2016; 23: 19890.

30. Ulmansky $M$, Hjørting-Hansen $E$, Praetorius $F$, Haque MF. Benign cementoblastoma: a review and five new cases. Oral Surg Oral Med Oral Pathol 1994; 77:48-55.

31. Neville BW, Damm DD, Allen CM, Bouquot JE. Oral and maxillofacial pathology. WB Saunders, Philadelphia, Pa, USA, 2nd edition, 2002.

32. Speight PM, Carlos R. Maxillofacial fibro-osseous lesions. Curr Diagn Pathol 2006;12:1-10.

33. El-Naggar AK, Chan JKC, Grandis JR, Takata T, Slootweg PJ. WHO classification of head and neck tumours. 4th Ed. Lyon: IARC, 2017.
34. Senia ES, Sarao MS. Periapical cemento-osseous dysplasia: a case report with twelve-year follow-up and review of literature. Int Endod J 2015;48:1086-99.

35.Cavalcanti $\mathrm{PH}$, Nascimento $\mathrm{EH}$, Pontual ML, Pontual $A D$, Marcelos PG, Perez DE, Ramos-Perez FM. Cemento-osseous dysplasias: imaging features based on cone beam computed tomography scans. Braz Dent J 2018;29:99-104.

36. Eversole R, Su L, ElMofty S. Benign fibro-osseous lesions of the craniofacial complex. Head and Neck Pathol 2008;2:177-202.

37. White SC, Pharoah MJ. Oral radiology: principles and interpretation, 7th edn. St.Louis, MO: Mosby Elsevier; 2014.

38.Regezi JA. Odontogenic cysts, odontogenic tumours, fibroosseous, and giant cell lesions of the jaws. Mod Pathol 2002;15:3:331-41.

39.McCarthy EF. Fibro-Osseous lesions of the maxillofacial bones. Head Neck Pathol 2013;7:510.

40.Ebenezer V, Ramalingam BA. Cross-sectional survey of prevalence of odontogenic tumours. J Maxillofac Oral Surg 2010;9:369-74.

41.Büyükkurt MC, Yalçın $E$, Aras M. Hamdi. Benign cementoblastoma: a case report. Atatürk Üni Diş Hek Fak Derg 2010;3:17-20.

42. Muğlalı M, Gündüz K, Gönülol AGDE, Günhan Ö. Florid semento-osseöz displazi: olgu raporu. Atatürk Üni Diş Hek Fak Derg 2011:73-6.

43. Yusof MY, Dasor MM, Ariffin F, Reduwan NH, Kamil WN, Mah MC. Idiopathic osteosclerosis mimicry of a tooth: case report. Aust Dent J 2020.

44. Farrokh F, Ruhani MR, Zarandi A. Frequency and pattern of idiopathic osteosclerosis and condensing osteitis lesions in panoramic radiography of Iranian patients. Dent Res J 2016;1:322.

\author{
Sorumlu Yazarın Yazışma Adresi \\ Büşra Arıkan \\ Inonu University, Faculty of Dentistry \\ Department of Oral and Maxillofacial Radiology, \\ Malatya, TURKIYYE \\ e-mail: busrakaradeniz0@gmail.com
}

